\title{
Pikiuuring õpetajaks õppijate professionaalse identiteedi kujunemisest
}

\author{
Katrin Poom-Valickis ${ }^{\mathrm{a} 1}$, Erika Löfström ${ }^{\mathrm{b}}$ \\ a Tallinna Ülikooli kasvatusteaduste instituut \\ ${ }^{b}$ University of Helsinki, Institute of Behavioural Sciences
}

\begin{abstract}
Annotatsioon
Artiklis antakse ülevaade viieaastase pikiuuringu tulemustest, keskendudes uuringus osalenud üliõpilastega õpetajakoolituse lõpus tehtud intervjuudele $(N=13)$. Artiklis otsitakse vastust küsimustele, kuidas õpetajakoolituse lõpetanud tudengid interpreteerivad enda õpetaja identiteedi kujunemist õpingute kaudu; milline on see õpetaja identiteet, mille poole soovitakse püüelda, lähtudes õpetaja ideaalist; ning millised on need põhitegurid, mis on mõjutanud tulevase õpetaja arusaamu õpingute käigus. Mittestruktureeritud intervjuus kasutati taustinfona ja intervjueeritavate mälutugedena nende poolt kolmel õpinguaastal kirja pandud metafoore õpetaja rolli kohta ning küsimustiku abil kogutud infot. Intervjuudest ja varasematest küsitlustest saadud info kõrvutamine ning analüüs võimaldavad paremini mõista aspekte, mis mõjutavad tulevaste õpetajate professionaalse identiteedi kujunemist. Tulemuste põhjal võib öelda, et õpetajakoolitust alustatakse naiivse ettekujutusega õpetaja tööst, lähtudes isiklikust varasemast koolikogemusest. Aine- ja klassiõpetajad väärtustavad õpetaja ideaali kirjeldamisel eri aspekte. Arusaamad õpetaja tööst ja rollist muutuvad õpingute jooksul komplekssemaks, õpetajakoolituse lõpus väärtustatakse enim pedagoogilist asjatundlikkust. Kõige tugevamalt mõjutab tulevase õpetaja arusaamu aga pedagoogiline praktika. Uurimuse tulemused võimaldavad paremini mõista algajate õpetajate arengut õpingute jooksul ning annavad viiteid õpetajate koolitajatele, kuidas tõhusamalt toetada professionaalse identiteedi kujunemist kui üht olulist aspekti õpetajahariduse omandamisel.
\end{abstract}

Võtmesõnad: õpetajakoolitus, identiteet, professionaalne identiteet

1 Kasvatusteaduste instituut, Tallinna Ülikool, Narva mnt 25, 10120 Tallinn; katrinpv@tlu.ee 


\section{Sissejuhatus}

Kool on kõik see, mis on õpetaja ... (Intervjuust)

Pidevalt muutuv maailm eeldab õpetajalt toimetulekut uute ülesannetega, pidevat õppimist ja uuenemist. Ühiskonna suurenenud ootused ei nõua õpetajatelt mitte ainult valmisolekut täiendada oma teadmisi ja oskusi, vaid ka soovi eksperimenteerida erinevate rollidega ning kujundada professionaalne identiteet, mis sobitub pidevalt muutuva kontekstiga. Õpetajate identiteedi kujunemist ja muutumist puudutavad uuringud on viimastel aastakümnetel olnud paljude pedagoogikateadlaste huviobjektiks (Akkerman \& Meijer, 2011; Anspal, Eisenschmidt, \& Löfström, 2012; Beijaard, 1995; Day, Kington, Stobart, \& Sammons, 2006; Flores \& Day, 2006; Leijen \& Kullasepp, 2013; Pillen, Brok, \& Beijaard, 2013; Thomas \& Beauchamp, 2007, 2011; Timoštšuk \& Ugaste, 2010). Kuigi professionaalse identiteedi mõiste defineerimises pole uurijatel selget üksmeelt (Akkerman \& Meijer, 2011; Beijaard, Meijer, \& Verloop, 2004), peetakse professionaalse identiteedi kujunemise ja mõju uurimist õpetaja õppimise ja töö seisukohalt ülioluliseks (Beauchamp \& Thomas, 2009). On leitud, et see, kuidas õpetaja tajub enda professionaalset identiteeti, mõjutab tema ametialast efektiivsust ja professionaalset arengut, samuti valmisolekut kohaneda muutustega ja võtta üle uuenduslikke käsitlusviise (Beijaard, Verloop, \& Vermunt, 2000).

Toetudes varasematele õpetaja identiteedi uurimustele, on Akkerman ja Meijer (2011) esitanud kolm olulist aspekti, mis iseloomustavad õpetaja professionaalset identiteeti. Esimene neist on identiteetide paljusus (multiplicity), st meie professionaalne identiteet koosneb paljudest alaidentiteetidest. Näiteks on siinses töös üliõpilaste metafooride analüüsi aluseks kasutatud Beijaardi jt (2000) mudelit õpetaja professionaalsest identiteedist, mille puhul võib eristada kolme alaidentiteeti: õpetaja kui ainespetsialist, pedagoog ja didaktikaekspert. Teiseks, õpetaja professionaalne identiteet on katkev (discontinuity), st see muutub pidevalt kogemuste tõlgendamise ja ümbertõlgendamise protsessis (Beijaard et al., 2004). Selle protsessi käigus otsitakse vastust küsimustele „Kes ma praegusel hetkel olen?” ja „Kuhu ma püüdlen?”. Kolmandaks, õpetaja professionaalne identiteet on sotsiaalne (social nature): professionaalne identiteet kujuneb indiviidi ja sotsiaalse keskkonna vastastikmõjus ning selles protsessis on tähtsal kohal nii algaja õpetaja elulugu, õpetajakoolitus kui ka pedagoogilisel praktikal saadud kogemused (Flores \& Day, 2006). 
Kõik kolm eeltoodud aspekti viitavad sellele, et professionaalne identiteet ei ole oma olemuselt kindel ja stabiilne, vaid pidevas muutumises ja arengus. Seetõttu on ka õpetaja professionaalse identiteedi kujunemist defineeritud kui „pidevat ja dünaamilist protsessi, mille käigus luuakse tähendusi ning (re)interpreteeritakse oma väärtusi ja kogemusi”, mis võivad olla mõjutatud nii personaalsetest, sotsiaalsetest kui ka kognitiivsetest faktoritest (Flores \& Day, 2006). Seega on õpetaja professionaalses ehk kutseidentiteedis põimunud identiteedi personaalne ja sotsiaalne mõõde (Karm, 2007) ning seda konstrueeritakse sotsiaalses kontekstis.

On oluline silmas pidada, et meie uskumuste, väärtuste ja hoiakute süsteem, mis loob aluse õpetaja identiteedile, kujuneb eelnevate kogemuste põhjal (Kagan, 1992). Õpetajakoolitusse tulijatel on aga seljataga juba kümneid tuhandeid tunde, mis on veedetud erinevates õpisituatsioonides, mille käigus on neil kujunenud implitsiitsed mudelid selle kohta, mida tähendab õpetada, juhtida klassi ja õppida (Lortie, 1975), ning arusaamad selle kohta, milline on hea õpetaja ja õppimine. Richardson (1996) esitab kolm kogemuste kategooriat, mis mõjutavad õpetajate õpetamisteadmiste ja -uskumuste kujunemist. Need on personaalsed mõjurid (õpetaja autobiograafia), varasem koolikogemus ja oppetajakoolituses saadud teadmised (sisaldavad nii aineteadmisi kui ka pedagoogilisi teadmisi). On leitud, et õpetajate uskumused toimivad kui filtrid, mis määravad, millised elemendid, sisuaspektid ja kogemused seotakse õpetaja teadmisbaasiga ning millised tõrjutakse eemale kui sobimatud (Calderhead, 1996; Joram \& Gabriele, 1998; Pajares, 1992). Seega infot, mida saadakse ülikooli kursustelt või ka klassiruumi jälgides, tõlgendatakse ja filtreeritakse läbi õpetaja personaalse pedagoogika.

Kuna need arusaamad õpetajaks olemisest on õpetajakoolitusse tulijatel erinevad, enamasti mitteteadvustatud kujutlused õpetaja tööst, kujuneb ka professionaalse identiteedi loomine tihti heitluseks erinevate, mõnikord võistlevate või vastukäivate perspektiivide, ootuste ja rollide vahel, millega üliõpilastel tuleb kas vastanduda või kohanduda (Beijaard et al., 2004). Siit tuleneb ka suur osa pingetest, mida õpetajaks õppijad õpingute ajal kogevad (Pillen et al., 2013).

\section{Refleksiooni ja ideaalide roll professionaalse identiteedi kujunemisel}

Uurijad on leidnud, et õpetajakoolituses pööratakse küll tähelepanu sellele, mida üliõpilased peaksid teadma ja oskama teha, kuid need püüdlused keskenduvad tihti väga spetsiifiliste teadmiste õpetamisele, näiteks kuidas planeerida tundi, juhtida klassi või toetada õppimist (Thomas \& 
Beauchamp, 2007), ning ei toeta piisavalt algaja õpetaja professionaalse identiteedi ülesehitamist ega üleminekut üliõpilase rollist õpetaja rolli (Freese, 2006; Smagorinsky, Cook, Moore, Jackson, \& Fry, 2004). Õpetajahariduses tuleks seetõttu suurem rõhuasetus seada sellele, kellena tulevane õpetaja end näeb või kellena soovib end näha, ning vähem sellele, mida ta teeb või peaks tegema. Kujutluse loomine endast kui professionaalist on oluline etapp efektiivseks õpetajaks kujunemisel (Thomas \& Beauchamp, 2007). Küsimused „Kes ma õpetajana olen?” ja „Kelleks ma tahan saada ehk mis on see ideaal, mille poole püüdlen?" on tähtsad nii identiteedi loomise kui ka professionaalse arengu vaatepunktist (Korthagen \& Vasalos, 2005). Pidev dialoog ideaali ja kogetud tegelikkuse vahel võimaldab indiviidil teadvustada eesmärke ning jälgida oma arengut ja tegevust professionaalina (Beauchamp \& Thomas, 2010; Lauriala \& Kukkonen, 2005). Seetõttu tuleks õpetajahariduses pöörata tähelepanu õppijate varasemate kogemuste teadvustamisele, jagamisele ja analüüsimisele ehk refleksiooniprotsessile. Refleksioon kui teadlikuks saamine enda pädevusest, aga ka uskumustest, hoiakutest ja väärtustest on see, mis annab meile ühelt poolt teadlikkuse ning teisalt võimaldab võtta ka vastutuse isikliku arengu eest. Beauchamp ja Thomas (2010) rõhutavad, et suur osa õpetajakoolituse käigus toimuvast refleksiooniprotsessist on paraku tagasivaatav (retrospective). Näiteks analüüsivad üliõpilased vaatluspraktikal tegevõpetajate tegevust tunnis, põhipraktikal aga reflekteerivad peale tunde enda tegevust õpetajana. Samas on oluline suunata tulevasi õpetajaid vaatama ka tulevikku, st mõtlema, milliseks õpetajaks nad soovivad saada. Kui nn tagasivaatav refleksioon toetub meenutustele, siis ettevaatav (anticipatory või prospective) refleksioon sisaldab kujutlusi ja unistusi ning on keskendunud tulevikuvõimalustele. Suunates üliõpilasi mõtlema sellele, milliseks õpetajaks nad soovivad saada, aitame õpetajaks õppijatel teadvustada, mis on see identiteedi osa, mis ei ole veel realiseerunud, kuid kuhu soovitakse jõuda (De Ruyter \& Conroy, 2002; Korthagen \& Vasalos, 2005). Teadlikuks saamist oma ideaalidest toetavad refleksiooniprotsessis küsimused „Mida sa soovid saavutada või luua?” ja „Milline on sinu õpetaja ideaal?”. Ka siinses uurimuses puudutas üks küsimustest tulevaste õpetajate ideaale.

Ideaalidel on tähtis koht meie arengus, sest nad loovad horisondi, kuhupoole püüelda, aitavad seada eesmärke, annavad meie püüdlustele tähenduse. Ideaalides peegelduvad need aspektid, mida me ise peame või mida teised peavad oluliseks. Samas, kui me ei usu, et oleme suutelised ideaalideni jõudma, võivad need olla ka demoraliseerivad (De Ruyter \& Conroy, 2002). 
Kuigi De Ruyter ja Conroy (2002) on uurinud ideaalide kujunemist kooliõpilaste näitel, võib eeldada, et samad ideaalide tekkimist mõjutavad aspektid kehtivad ka üliõpilaste, st tulevaste õpetajate kohta (Beauchamp \& Thomas, 2010). De Ruyter ja Conroy (2002) peavad ideaalide kujunemisel oluliseks kolme komponenti, milleks on a) mingil ajal imetletud inimeste tähtsus, b) ettekujutus ihaldusväärsest olukorrast, millesse end kujutleme, ning c) isikuomadused, mis on seotud ühiskondlike arusaamadega ja konkreetsele rollile esitatavate normide ja ootustega. Kuna identiteet on sotsiaalselt konstrueeritud, siis on ka ideaalide kujunemisel suur osa inimestel, kes on meid meie eluteel mõjutanud. Õpetaja professionaalse arengu uuringud on näidanud, et see, millisena õpetajakoolituse üliõpilased näevad enda rolli tulevikus, on suurel määral mõjutatud situatsioonidest ja indiviididest nende elus (Furlong, 2013; Kelchtermans \& Vandenberghe, 1994), kusjuures õpetajate rollimudeliteks on enamjaolt nende endi kunagised õpetajad (Furlong, 2013; Korthagen, 2004). Ent nii nagu identiteet, muutuvad ja arenevad koos saadud info ja kogemuste hulgaga ka meie ideaalid. Refleksiooniprotsess võimaldab meil neid muutusi teadvustada ja mõista.

Siinses artiklis keskendutaksegi pikiuuringu lõpus tehtud intervjuudele, täpsemalt on huvi keskmes õpetajakoolituse läbinud õppijate tagasivaade oma professionaalse identiteedi kujunemisele viie õpinguaasta jooksul. Uurimuse eesmärk oli analüüsida õpetajakoolituse üliõpilaste õpetajaidentiteedi aluseks olevaid tähendusi ja uskumusi, mis on loodud interaktsioonis keskkonnaga, sh ülikooli õpingute käigus kogetuga. Mälutugedena kasutati intervjueeritavate poolt õpingute jooksul kirja pandud metafoore ning varasemate küsitluskordade andmeid. Artiklis otsitakse vastust küsimustele, kuidas õpetajakoolituse lõpetanud tudengid interpreteerivad enda õpetajaidentiteedi kujunemist õpingute kaudu; milline on see õpetaja identiteet, mille poole soovitakse püüelda; millised tegurid on õpingute käigus tulevase õpetaja arusaamu kõige rohkem mõjutanud.

\section{Uurimuse metoodika ja valim}

Artiklis kasutatud andmete kogumisega alustati 2008. aastal, mil läbilõikeuuringu raames küsitleti bakalaureuse esimese ja kolmanda aasta ning õpetajakoolituse magistritaseme üliõpilasi. Kahe aasta pärast küsitleti jätku-uuringu raames uuesti 2008. aastal bakalaureuse esimesel aastal õppinud üliõpilasi $(N=310)$ nende kolmandal õppeaastal $(N=163)$ ning õpetajakoolitusse suundunud üliõpilasi $(N=55)$ nende magistriõpingute lõpus. Ülevaate pikiuuringu käigus eri aastatel kogutud andmetest annab 
lisa 1. Küsitlustega kogutud andmetest ja tulemustest on võimalik lugeda täpsemalt varem ilmunud artiklitest (Löfström, Poom-Valickis, Hannula, \& Mathews, 2010b; Löfström \& Poom-Valickis, 2013). Siinses artiklis keskendutakse eelkõige õpetajakoolituse õpingute lõpus tehtud intervjuu küsimustele, mis aitavad mõista, milline on see õpetaja ideaal, mille poole soovitakse püüelda (ideal self) seoses valitud professiooniga, ning kui kaugel enda hinnangul sellest ideaalist hetkel ollakse (lisa 1, intervjuu küsimused 4 ja 5).

Kas Sul on ettekujutus sellest, milline õpetaja Sa tahaksid olla? Kas Sa palun kirjeldaksid seda? Kui kaugel Sa enda arvates hetkel kümnepalliskaalal sellest ideaalist oled? Kuidas Sa arvad, et jõuad selle ideaalini?

Samuti huvitas uurijaid, mil moel on õpetaja identiteedi kujunemine seotud arusaamade muutumisega professionaalsest rollist ning mis on neid muutusi mõjutanud (lisa 1, intervjuu küsimus 1 ).

Vaadates tagasi viiele õpinguaastale ülikoolis, siis mis on olnud need olulised pöördepunktid või sündmused, mis on mõjutanud Sinu arusaamu õpetamisest ja õppimisest? Kui Sinu arvamused, arusaamad on õpingute jooksul muutunud, siis miks?

Mittestruktureeritud intervjuu käigus kasutati intervjueeritavate mälutugedena nende poolt õpingute käigus (st 1., 3. ja 5. õpinguaastal korraldatud küsitluste ajal) kirja pandud metafoore ópetaja rolli kohta, mis võimaldas intervjueeritaval analüüsida oma arusaamade muutumist (lisa 1, intervjuu küsimus 6).

Sa oled kirjeldanud õpetaja rolli selliste metafooride kaudu nagu .... ja .... ja .... Mis võisid olla need põhjused, et kirjeldasid õpetaja rolli just nii? Kas sooviksid nüüd kasutada teistsugust metafoori?

Lisaks analüüsiti intervjueeritavate poolt eri õpinguaastatel kirja pandud metafoore ning neis peegelduvat arusaama õpetaja rollist. Pikiuuringu raames korraldatud küsitlustes pidid üliõpilased kolmel korral leidma metafoori, mis iseloomustaks õpetaja rolli õpetamisel ja õppimisel, ning seda ka põhjendama. Bullough' (1991) kohaselt peegeldavad metafoorid õpetajate arusaamu õpetamisest ja õpetaja rollist ehk teisisõnu väljendavad need õpetajate professionaalset identiteeti ning on osutunud sobivaks vahendiks õpetajate uskumuste uurimisel (Alger, 2009; Leavy, McSorley, \& Bote, 2007; Martínez, Sauleda, \& Huber, 2001; Pinnegar, Mangelson, Reed, \& Groves, 2011; Saban, 2004, 2010). 
Taustinfona kasutati peale intervjuude kolmel õpinguaastal küsimustiku abil kogutud infot intervjuus osalenud üliõpilaste akadeemilise enesetõhususe, õpetajakoolituse/õpetajakutse valiku kindluse ning enda kui õpetaja enesetõhususe kohta (lisa 1).

Pikiuuringu valimisse kuulunud üliõpilastest 13 intervjueeriti vahetult enne ülikooli lõpetamist. Intervjuudes osalemine oli vabatahtlik, viimasel õppeaastal tehtud küsitluse lõpus paluti vabatahtlikel kirja panna enda e-posti aadress, mis võimaldas uurijatele intervjuus osalemise nõusoleku andnud üliõpilastega hiljem kontakteeruda. Uurijate hilisematele e-kirjadele intervjuus osalemise kohta vastas 13 üliõpilast, kellest 5 olid tulevased klassiõpetajad ja 8 tulevased aineõpetajad. Intervjueeritutest 12 olid naised, 7 üliõpilast olid õpingute ajal õpetajatööd alustanud ning neil oli 0,5-3-aastane õpetajatöö kogemus.

\section{Andmete analüïs}

Õpetajakoolituse lõpetajatega tehtud intervjuud lindistati ja transkribeeriti. Intervjuude kaudu kogutud andmete analüüsimiseks kasutati temaatilist analüüsi, mis võimaldab uurimisandmestikust leida, analüüsida ja esitada mustreid või teemasid ning annab ühtlasi võimaluse uurimisandmestikku detailselt kirjeldada (Braun \& Clarke, 2006). Avatud kodeerimise kaudu identifitseeriti esimese sammuna andmetes esinevad teemad. Järgnevalt jaotati identifitseeritud teemad laiemate kategooriate alla ning lõpuks kodeeriti kogu andmehulk eristatud kategooriate põhjal uuesti.

Artikli tarbeks analüüsiti varasematel õpinguaastatel intervjueeritavate kirja pandud metafoore koos selgitusega, tuginedes Beijaardi, Verloopi ja Vermunti (2000) mudelile, mille kohaselt kujundab õpetaja oma professionaalset identiteeti selle kaudu (tavaliselt neid viise kombineerides), kuivõrd ta näeb end kui ainespetsialisti, pedagoogi ja didaktikaeksperti. Ainespetsialisti kategooriasse liigitati metafoorid, mis rõhutasid eelkõige õpetaja aineteadmisi ning tema rolli teadmiste ülekandmisel õpetajalt õpilasele. Õpetaja pedagoogiline asjatundlikkus hõlmab Beijaardi jt (2000) kohaselt eelkõige arusaama õpetajatöö eetilistest aspektidest. Siia kategooriasse kuulusid metafoorid, mis rõhutasid õpetaja kui eeskuju, kasvataja, aga ka probleemide, konfliktide lahendaja rolli. Õpetaja kui didaktikaekspert pöörab tähelepanu õppeprotsessi kavandamise, juhtimise ja hindamise oskustele, mistõttu liigitati siia kategooriasse metafoorid, kus õpetajat nähti eelkõige õppimist toetava õpikeskkonna looja ja õppimise juhendajana. Metafoore analüüsisid eraldi 
mõlemad autorid, kooskõla metafooride kodeerimisel oli 84\%. Eri õpinguaastatel intervjueeritavate kirja pandud metafoorid pakkusid suurt tuge intervjuude ajal, sest võimaldasid intervjueeritavatel toimunut meenutada, luua seoseid ning reflekteerida enda arusaamade muutumist õpingute käigus. Seega kasutati üliõpilaste metafoore intervjuudes mälutugedena (vt lisa 1, küsimus 6) ning neid analüüsiti ka iseseisvalt, toetudes eelkirjeldatud Beijaardi jt (2000) mudelile.

Peale intervjuude ja metafooride kasutati taustinfona ka intervjueeritavate poolt varasematel aastatel küsimustikes antud vastuseid. Parema ülevaate saamiseks intervjueeritud rühma sisestest erinevustest ja sarnasustest tehti klasteranalüüs eukleidilise kauguse põhjal. Analüüsi kaasati need küsimused (akadeemiline enesetõhusus, kindlus õpetajakoolituse/ õpetajakutse valikul ning enesetõhusus õpetajana koos alaskaaladega), millele intervjueeritud üliõpilased olid vastanud nii bakalaureuse esimesel ja kolmandal aastal kui ka magistriõpingute lõpus (vt lisa 1). Klasteranalüüsi tulemused andsid ülevaate intervjueeritud üliõpilaste rühma sisestest erinevustest. Oli üliõpilasi, kelle enesehinnang oli eri valdkondades püsivalt parem või pigem halvem, ning neid, kelle hinnangud endale eri valdkondades kõikusid õpingute jooksul. Klasteranalüüsi tulemuste võrdlemine intervjuudes ilmnenud teemadega andis võimaluse tuvastada teatud mustrite ja tüüpide esinemist õpetajakoolituse üliõpilaste hulgas.

\section{Tulemused}

Töös käsitletakse identiteeti kui muutuvat arusaama iseendast ja oma professioonist, mida konstrueeritakse sotsiaalses kontekstis, toetudes kogemuste käigus omandatud uskumuste, hoiakute ja väärtuste süsteemile. Küsimused „Kes ma olen?”, „Milliseks õpetajaks ma tahan saada?” ja „Kuidas ma näen enda rolli õpetajana?” on õpetaja professionaalse identiteedi arengut silmas pidades olulised (Korthagen, 2004). Ent nii nagu meie identiteet, on ka meie kujutlus endast kui professionaalist ajas muutuv ning seotud meie teadmiste, kogemuste ja arusaamadega. Tulemuste tutvustamisel vaadeldakse kõigepealt, milline on see õpetaja ideaal, mille poole õpetajakoolituse lõpetajad püüdlevad. Esmalt antakse ülevaade sellest, milline on intervjueeritud üliõpilaste arusaam ideaalsest õpetajast, millised tegurid on selle ideaali loomist mõjutanud ning kui kaugel ollakse enesehinnangu põhjal õpetajana sellest ideaalkujutlusest. Teiseks võimaldavad intervjuud ja intervjueeritavate poolt õpingute ajal kolmel korral kirjutatud metafooride analüüs selgitada, kuidas on 
arusaamad õpetajaks olemisest õpingute jooksul muutunud ning mis on olnud olulisemad tegurid arusaamade muutumisel.

Uurijatel ei olnud alguses plaanis kirjeldada erinevaid óppijate profiile ning seetõttu ei peegeldu need ka esialgsetes uurimisküsimustes. Andmete analüüsil ja erinevate meetoditega kogutud andmete võrdlemisel ilmnes, et mõningad omadused esinesid uuringus osalenute seas korduvate mustritena. Kuigi õpetajakoolitusse tulijate kogemuste taust on erinev, tundus eristuvat neli õpetaja identiteedi profiili, mis on kujunenud erinevate aspektide mõjul. Artiklis antakse ülevaade leitud profiilidest ning teguritest, mis on mõjutanud üliõpilaste professionaalse identiteedi kujunemist.

\section{Õpetaja ideaalid ja nende kujunemine}

Õpetajakoolituse ajal konstrueerivad tulevased õpetajad enda kui tulevase õpetaja identiteeti, toetudes oma varasematele koolikogemustele, ideedele ja käsitlusviisidele, mida on rõhutatud õpetajakoolituses, ning kujutlusele ideaalsest õpetajast, kelleks nad tahavad saada.

On leitud, et identiteedi sotsiaalse konstrueerimise olulisim aspekt on just ühiskondlikest normidest ja ootustest ning väärtustest moodustunud ideaal, mis toimib eesmärgina, mille poole püüelda (vt Haamer, 2012). Kõigil küsitletutel oli ettekujutus endast kui ideaalsest õpetajast. Analüüsides ideaalse õpetaja kirjeldust, vaadeldi, kas osalejad keskendusid oma ettekujutuse kirjeldamisel eelkõige endale ja soovitavatele isikuomadustele või seadsid fookuse muule, näiteks õpetamisele, suhetele õpilastega, kaaskolleegidega.

Analüüside põhjal võib öelda, et õpetatav aine avaldab aineõpetaja identiteedile suurt mõju. Tulevased aineõpetajad seadsid ideaalse õpetaja kirjeldamisel esikohale õpetatava ainega seotud aspektid, st ideaalne aineõpetaja „suudab aine huvitavaks teha, valdab ainet, õpilased naudiksid ainet, suudab panna matemaatikat armastama, õpiksid kunsti hindama ja analüüsima, aine patrioot”. Ideaalõpetaja kirjeldamisel on tähtsal kohal õpetaja kui juhendaja oskused: „Õpetaja kui juhendaja - annab baasi, aga mõtlevad ise, õpetaja pigem vaikne, õpilased suhtleksid, grupijuht, mõtlemis- ja analüüsivõime arendamine, õpilased jõuaksid ise teadmisteni, suhtleksid omavahel, looksid, saavutaksid ise." Ka Beijaard (1995) leidis oma uuringus, et keskkooli õpetajate (st aineõpetajate) professionaalne identiteet on tuletatud eelkõige ainest, mida nad õpetavad, ning sel on tugev ja pidev mõju arusaamadele enesest kui professionaalist. 
Tähtsal kohal aineõpetajate ideaali kirjeldustes on ka distsipliin, kord ja enesekehtestamine. Samas tuntakse muret, kuidas seda saavutada, sest soovitakse, et "kord ja vabadus oleks tasakaalus”, ning tahetakse olla korraga „range ja leebe, sõber ja lugupeetud”. Õpetaja professionaalset arengut mõjutavad ka suhted õpilastega. Ühelt poolt eeldatakse, et õpetajad peaksid näitama üles personaalset huvi ja respekti iga õpilase suhtes ning teisalt säilitama ka distantsi. Tasakaalu leidmine kahe poole vahel tundub olevat üks aspekte, mille saavutamise poole oma ideaalides püüeldakse. Siinkohal on oluline silmas pidada, et mida enam on personaalne ja professionaalne mina integreeritud õpetaja identiteedis, seda enam on õpetaja ka mõjutatav õpilaste negatiivsest ja positiivsest käitumisest (Beijaard, 1995).

Erinevalt klassiõpetajatest ei nimeta aineõpetajad ideaalse õpetaja kirjeldamisel personaalseid omadusi, vaid kirjeldavad oma ideaali eelkõige õpetaja oskuste ja klassisituatsiooni kirjelduse kaudu. Intervjueeritud aineõpetajatest märgib vaid üks, et ideaalne õpetaja on positiivne. Samas on aga kõigile aineõpetajatele omane soov, et õpilased austaksid neid. Ideaalse õpetaja kirjeldustes on olulised märksõnad austus ja lugupidamine.

Kuna klassiõpetajad õpetavad mitut ainet, siis ei peegeldu ideaalide kirjelduses mitte niivõrd konkreetse aine vastu huvi äratamine, vaid kogu õppeprotsessi muutmine õppijakeskseks. Kõik klassiõpetajad rõhutavad tundide ettevalmistamise olulisust, paindlikkust õppeprotsessis ning valmisolekut oma tegevusi muuta, sest lapsed väsivad, nende tähelepanu hajub. Ideaalne õpetaja muudab tunnid nii põnevaks, et „nad vaatavadki, suu ammuli, seal ja ma ei näeks mingeid tüdinud nägusid. Pakub hästi palju atraktiivseid ülesandeid ja kui sa näed, et tund ei lähe nii, nagu planeeritud, et siis oleks kohe ideid, et mida muuta, et mida ette võtta", lisaks „jõuda välja nende lastega hästi palju ja jõuda muuseumidesse ja jõuda ekskursioonidele; teha ekskursioone, minna koolist välja, klassist välja, teha tunde väljaspool".

Ideaalne klassiõpetaja tunneb lapsi ja hoolitseb selle eest, et lapsed tunneksid end kindlalt. Õpetaja puhul hinnatakse, et ta oleks oma olemuselt „energiline, rõõmus, konkreetne, paindlik, aktiivne”. Õpetajana soovitakse olla „suureks eeskujuks lastele”.

Seega võib öelda, et kui ideaalse õpetaja kirjeldustes domineerivad aineõpetajate puhul aine ja aine õpetamisega seotud aspektid, siis klassiõpetajad on enam keskendunud suhetele õpilastega ja õppeprotsessile kui tervikule. Aineõpetaja ideaal on saada õpetajaks, kes on lugupeetud ja keda õpilased austavad, ent ideaalne klassiõpetaja on aktiivne, rõõmus 
ja paindlik ning õpilastele eeskujuks. Huvitaval kombel peegelduvad vaid kahe üliõpilase ideaalides kaaskolleegide ja kooli kui organisatsiooniga seotud ootused: „... ma tahaks ka selle kooli, selle muu õhkkonna või noh, töötajate ja asjadega hästi kohaneda, et mulle ei meeldi olla selline üksi ja eraklik, ma tahaks kohe kõigiga suhelda ja et kõik võtaksid mind omaks."

Kuigi õpetaja identiteeti mõjutavad välised (poliitika), sisemised (organisatsioon) ning nii minevikus kui ka tulevikus saadavad personaalsed kogemused (Day et al., 2006), seostavad üliõpilased oma ideaalse õpetaja kuvandit esialgu eelkõige klassiruumiga. Need tulemused on sarnased Furlongi (2013) uuringu omadega, kus ilmnes samuti, et a) üliõpilaste ideaalse õpetaja kirjeldustes domineerivad teemad on seotud õpetaja isikuomadustega, st hea õpetaja on soe, hoolitsev, entusiastlik; b) ideaalse õpetaja kirjelduses on olulisel kohal suhted õpilastega, st õppijatelt oodatakse lugupidamist, soovitakse olla õpetajaks, kes jääb õppijatele meelde; c) ideaalne õpetaja suudab juhtida edukalt óppeprotsessi, muuta aine huvitavaks ning tuleb toime klassi juhtimisega.

Kuigi tulevaste aine- ja klassiõpetajate ideaalide kirjeldamisel on mõningaid sarnasusi, mis on seotud kas aine või vanuseastmega, kus tulevikus õpetama asutakse, siis ei ole ideaali kujundamisel olulised sugugi mitte kõik asjaolud, mida mingil ajal tajutakse imetlusväärsena, vaid üksnes need, mida jagatakse ka teistega ja millele antakse isiklik tähendus. Ideaalide loomist mõjutab kindlasti ka nende inimeste tähtsus, keda on mingil hetkel imetletud. Mitmed intervjueeritavad nimetasid oma kunagist õpetajat kui ideaalset rollimudelit, kelle moodi soovitakse olla.

... mul on selles mõttes hea, et ma mõtlen ühe õpetaja peale, kelle moodi ma tahan olla, ... selline õpetaja, kes saab õpilastega vabalt suhelda ja luua sellise vaba ja sõbraliku ja sellise otsese suhtluse klassis, aga ometi neil on nagu lugupidamine ja neil on nagu piinlik, kui neil jäävad asjad maha, või et neil on nagu selline ... respekt nagu sinu suhtes, ma ei kujuta ette, kuidas seda teha.

See on minu bioloogiaõpetaja, kes oli natukene selles suhtes, et ta on range mõne koha pealt, et klassis on vaikus, ei ole mingit lärmamist, mitte midagi, et oli siuke konkreetne ja range, aga samas oli väga mõistev õpetaja.

Suur osa intervjueeritavatest kirjeldas oma ideaali n-ö ideaalsete olukordade kaudu, milleni soovitakse jõuda.

Ma tahan, et õpilased võtaksid mind omaks, et ma ei jääks neile kuidagi kaugeks, et nad, nad julgeksid oma murede ja asjadega 
minu juurde ka tulla, et ma ei oleks nagu lihtsalt õpetaja, ma oleks ka nende, no ka sõber, see pole nagu õige sõna, aga ... usaldusisik, midagi sellist.

De Ruyter ja Conroy (2002) nimetavad ideaalide kujunemise ühe osana samuti situatiivset komponenti. Ideaalide tekkimist mõjutavad meie isiklikud kogemused ning nende reflekteerimise kaudu teadvustatud ihaldusväärne olukord ja võimalik strateegia selleni jõudmiseks. Ka Furlong (2013) tõdeb oma uurimuses, et tulevaste õpetajate ideaalides peegelduvad suuresti nende endi õpetajad ja koolikogemused. De Ruyteri ja Conroy (2002) kohaselt kujundavad ideaali ka isikuomadused, mis on seotud ühiskondlike arusaamade ja rollile esitatavate nõuetega. Näiteks oodatakse õpetajalt üldjuhul positiivsust, täpsust, korrektsust, samuti ainealast kompetentsust, häid suhtlemis- ja klassijuhtimisoskusi. Ka need aspektid peegeldusid intervjueeritavate ideaalide kirjeldustes: „õpetaja, kes valdab ainet ..., suudab ellu viia demonstratiivkatseid, noh, nii palju kui see on kooli vahenditega võimalik, samas olla piisavalt range, kuid piisavalt leebe, mõista õpilast."

Intervjueeritavate hinnangud selle kohta, kui kaugel on nende praegune mina ideaalsest minast, kõikusid kümnepalliskaalal neljast kaheksani. Kõige lähemal oma ideaalminale olid üliõpilased, kes olid varasemate, küsimustikega kogutud andmete kohaselt andnud rühmas kõige kõrgemad hinnangud oma enesetõhususele õpetajana ehk neil oli suurem usk oma toimetulekusse. Kümnepalliskaalal arvati, et hetkel ollakse 7 või 8 juures. Teiste rühmade esindajad hindasid enda kaugust ideaalist suhteliselt sarnaselt ning see jäi 4-6 palli vahele. Õpetajatöö kogemusega üliõpilasi iseloomustas enda võrdlemisel ideaaliga teistest põhjalikum eneseanalüüs, kus erinevatele osaoskustele anti erinevaid hinnanguid. Näiteks, „mõtlemise arendamises olen 6, näitlikustamises 4 või suhtlemisel olen 6, aga teadmised erinevatest tehnikatest 4".

Kokkuvõttes võib öelda, et algajatel õpetajatel on selge ettekujutus ideaalist, milline õpetaja tahetakse olla, kuid pole täit selgust või kindlust selles, kuidas oma ideaalini jõuda. Kümme õpetajat kolmeteistkümnest arvasid, et ideaalini jõudmiseks on vaja eelkõige töökogemust, st praktikat. Vaid kolm õpetajat tõid eneserefleksioonile toetudes esile konkreetseid aspekte, mida tuleks esmajoones arendada, näiteks teatud tehnikate või ainevaldkonna parem tundmine, järjekindlus ja süsteemsus klassireeglite kehtestamisel, probleemide lahendamisel. Samas on mõtlema panev tõsiasi see, et ükski intervjueeritav ei maininud eneseanalüüsi või 
oma töö analüüsi ega õppijate või kolleegide tagasisidet kui võimalust, millele oma õpetamise arendamisel toetuda või millest õppida.

Õpetamiskogemus on kindlasti oluline, kuid silmas tuleb pidada seda, et kogemus ilma refleksioonita, st ilma et kogemusele antakse tähendus, ei õpeta (Berliner, 1987). Kogemusest õppimist toetab kogemuste sõnastamine, nende jagamine, analüüsimine ja suhestamine teoreetiliste teadmistega. Teisalt võib töökogemuse olulisuse rõhutamine olla seotud ka sellega, et pedagoogiline praktika õpingute ajal toimub ikkagi n-ö turvatud keskkonnas ega anna täit kindlust iseseisvaks toimetulekuks: „praktikal oli ju niimoodi, et see aineõpetaja istus seal klassis tagaotsas ja klass võib-olla kartis teda, aga ma ei ole ju üksinda klassiga olnud kunagi, seda ma kardan."

Kuna ka need intervjueeritavad, kes juba töötasid, rõhutasid ideaali poole jõudmisel töökogemuse osatähtsust, võib arvata, et algaja õpetajana ollakse alles enda professionaalset enesekontseptsiooni loomas ning ilmselt veel ei väärtustata ópetajakoolituses refleksiooni rolli õppimises piisavalt.

\section{Õpetaja rolliga seotud arusaamade muutumine}

Meie ideaalid muutuvad koos meie arusaamade ja väärtustega erinevate kogemuste, sh õpingute käigus. Varasemad uuringud on näidanud, et ópetajakoolitusse tulijatel on selged arusaamad õpetamisest ning need on kujunenud nende kümnete tuhandete tundide jooksul, mis on veedetud oppijana erinevates õpisituatsioonides, internaliseerides mudeleid heast ja halvast õpetamisest (Calderhead, 1996; Joram \& Gabriele, 1998; Kagan, 1992; Lortie, 1975; Pajares, 1992). Need arusaamad õpetaja tööst tuginevad isiklikule koolikogemusele õpilasena ja sellele, mida õpilasena klassiruumis ning õpetaja tegevuses tähele pandi.

... ma tulin bakaastmesse ainult selle teadmisega, mida mina ise olin koolis näinud, kui ma õppisin, et missugune oli minu eesti keele ópetaja. Aga, aga ma ju ei teadnud, kuidas ta neid asju teeb, mida ta tegi.

Intervjuudest ilmneb, et õpetajakoolitusse tulles oli intervjueeritavatel õpetamisest naivistlik arusaam.

Alguses tundus, et mis seal siis ikka ära ei ole, et ... et on lihtne, aga tegelikult see, isegi mitte ainete õpetamine, et aga see, et lapsed saada enda ... nagu tegema seda, mida nad peavad tegema, et 
omavahelised suhted ja suhtlemine lapsevanematega, et see on hoopis teine asi.

... alguses, kui oli ettekujutus, et no lähen lastega trillallaa-trallallaa, aga tegelikult et no jah, et praktikatel ... tuli see arusaam, et see on ikkagi suur töö tegelikult.

Naivistlikud võisid olla ka põhjused, millega õpetajakoolitusse tuldi.

Kui ma alguses tulin, ma ei teadnud sellest eriti midagi. Ma teadsin, et ma tahaksin saada õpetajaks, ja ikka oli selline arusaam, et oh, ópetajatel on mitu puhkust ja vaheajad, aga tegelikult jaa, et see on hoopis midagi muud, mida tegelikult teised inimesed teavad.

Arusaam, et õpetajatöö ei seisne vaid tunni andmises ja pikas puhkuses, muutub intervjueeritavate jaoks reaalsuseks esimeste praktikate ja õpetajakoolituse ainete kaudu. Meid kui uurijaid huvitas aga ka see, kuidas ja mil määral on muutunud tulevaste õpetajate uskumused õpetaja rollist ning juhul, kui muutused on toimunud, siis millega neid seostatakse. Analüüsi aluseks võeti intervjueeritavate poolt kolmel õpinguaastal kirja pandud metafoorid, mida analüüsiti Beijaardi jt (2000) mudeli põhjal. Kuigi kõik kolm aspekti - ainespetsialist, pedagoog ja didaktikaekspert - on õpetajatöös olulised ning moodustavad kombineeritult enamasti ka õpetaja identiteedi aluse, peegeldab ühe või teise aspekti rõhutamine seda, mida algajad õpetajad sel hetkel enim väärtustavad.

Võrreldes metafoore, mida intervjueeritavad kirjutasid õpingute alguses ja lõpus, võib öelda, et arusaam õpetaja rollist on muutunud mitmekülgsemaks. Kui õpingute alguses oli ühedimensioonilisi, st vaid üht aspekti - ainespetsialisti, pedagoogi või didaktikaeksperdi rolli rõhutavaid metafoore kümme, siis magistriõpingute lõpus on neid kuus. Seega võib öelda, et õpingute käigus on õppijate arusaam õpetaja rollist laienenud, suur osa metafooridest on hübriidid: õpetaja rolli kirjeldamisel peetakse oluliseks erinevaid aspekte, näiteks ainet ja pedagoogilist kompetentsust, ainet ja didaktikat või pedagoogikat ja didaktikat. Samamoodi nagu varasemates analüüsides kogu uuringus osalenud valimiga (Löfström, Anspal, Hannula, \& Poom-Valickis, 2010a), rõhutati ka intervjueeritud rühma metafoorides õpetaja kui pedagoogi rolli. Pedagoogilist pädevust pidas õpetajakoolituse lõpus kirjutatud metafoorides oluliseks üheksa õppijat kolmeteistkümnest. Nendest kolm olid n-ö puhtad metafoorid: neis rõhutati vaid õpetaja kui pedagoogi ja kasvataja rolli. 
Õpetaja on nagu koolipoolne lapsevanem. Kuna ta on inimene, kes seisab lapsele peale tema vanemate kõige lähemal. Tal on oma reeglid, millest tuleb kinni pidada, nagu igas kodus on reeglid. Ta püüab õpilast eluteel juhendada nagu ema või isa ning täpselt samuti hoolib lapsest.

Õpetaja kui pedagoogikaekspert on Beijaardi jt (2000) kohaselt seotud eelkõige arusaamaga õpetajatöö eetilistest aspektidest. Õpetaja kui eeskuju, kasvataja, aga ka probleemide, konfliktide lahendaja peab olema nendest aspektidest teadlik ja arvestama nendega nii õpilastega suheldes kui ka õppetööd läbi viies. Beijaard jt (2000) on leidnud, et paljud õpetajad peavad just pedagoogilist poolt oma töös olulisemaks kui didaktilist või ainealast.

Õpetajakoolituse lõpus ei näe keegi intervjueeritud üliõpilastest õpetajat vaid ainespetsialistina. Õpingute alguses oli selliseid üliõpilasi intervjueeritavatest kaks. Aineeksperdi metafoorides avaldub õpetaja kui teadmiste valdaja ja jagaja roll.

Õpetaja on nagu infoportaal, sest õpetaja on alati see kõige-kõige targem, ja nii kui tema käest midagi küsida, teab ta kõike - kui mitte kohe, siis ta otsib välja ja lõpuks teab ikkagi kõike.

Ainealast asjatundlikkust peetakse õpetajaks olemisel küll oluliseks ja see peegeldub ühe aspektina pedagoogilise või didaktilise kõrval pooltes õpetajakoolituse lõpus kirjutatud metafooridest. Huvitaval kombel ilmneb õpetaja ainealase asjatundlikkuse olulisus just kõigi klassiõpetajate ja vaid ühe aineõpetaja metafooris. Samas professionaalse ideaali kirjeldamisel rõhutasid aine ja selle õpetamisega seotud aspekte just aineõpetajaks õppijad. Vastuolu võib olla seotud sellega, et klassiõpetajad õpivad viieaastasel integreeritud õppekaval, milles kesksel kohal ei ole mitte aine, vaid õppija arengu toetamine, juhendajaks, kasvatajaks olemine. See arusaam tuli esile ka klassiõpetajate ideaalide kirjelduses. Metafoore kirjutades tuli aga mõelda õpetaja rollile, õpetaja tööle. Kuna klassiõpetajatelt eeldatakse erinevate ainete head valdamist ning, nagu intervjuudest ilmnes, mitte kõigis ainetes ei tunta end ühtmoodi kindlalt, on võimalik, et ainetundmise olulisus peegeldus just seetõttu klassiõpetajate metafoorides.

Didaktikaeksperdi kategooriasse liigitatud õpetajakoolituse üliõpilaste metafoorid väljendasid arusaama, et kõige olulisem õpetajatöös on oskus juhtida õppeprotsessi ning selleks, et see protsess oleks tõhus, tuleb arvestada õppijatega. Vajaduse korral tuleks neid ka motiveerida või muuta 
enda kui õpetaja tegevusviisi: „Õpetaja on nagu teeviit. Õpetaja peab suunama õpilasi õppima ja saama eluks vajalikke teadmisi.”

Intervjueeritud üliõpilaste rühmas olid kõigi metafoorid muutunud õpingute jooksul kas komplekssemaks, st algsele ühedimensioonilisele metafoorile oli õpingute jooksul lisatud mõni uus aspekt, või oldi oma esialgsest metafoorist loobutud. Metafoorides peegelduv muutus on kooskõlas ka intervjuudega, sest kõik intervjueeritavad leidsid, et nende arusaamad on õpingute jooksul muutunud. Uurijaid huvitas, kuidas interpreteerivad intervjueeritavad metafooride muutusi ning milliseid tegureid peetakse olulisemateks.

Üliõpilaste vastuste analüüs osutab järgmistele tendentsidele. Bakalaureuseõpingute ajal kirjutatud metafoorides peegeldub intervjueeritavate sõnul ettekujutus enda ideaalõpetajast: „Ei noh, mis mõttes õpetaja teab kõike, ei tea kõike ja ei peagi teadma ... see esimene, see oli mul keskkoolis juba siuke, millegipärast arvamus, sest minu eesti keele õpetaja oli tõsiselt väga, väga tark tõesti, intelligentne inimene ja siis ma arvasingi jah, et ilmselt, et, et siis ta teab kohe kõike ja kõiki." Samuti väljendavad need isiklikul koolikogemusel põhinevat arvamust, et „sa ainult nagu teed õpetamistööd ja midagi muud seal nagu ei olegi”.

Seega samamoodi nagu õpetaja ideaalide kujunemise puhul, on üliõpilaste endi varasemad õpetajad ja koolikogemus olulised ka õpetaja rolli, st kutsealal sotsiaalselt oodatava käitumise ja eeldatava pädevuse mõtestamisel. Bakalaureuseõpingute ajal kirjutatud metafoore mõjutasid peale isikliku varasema koolikogemuse ka ülikooliõpingud, sh eelkõige aineõpingute kesksus: „... aga see ehitaja, no jah siis ma olin väga selline oma eriala keskne, ma ei mõelnud siis veel õpetamise peale kui võimaluse peale ..."

Muutusi oma arusaamades õpetaja rollist ja seega metafoorides magistritasemel selgitatakse õpetajakoolituse käigus kujunenud selgema arusaamaga õpetaja rollist.

Mina pigem võtsin ennast kui õpilast, et minu jaoks on oluline see, et õpetaja annaks mulle teadmised. Et aga siin on, nagu võtan ma ennast kui õpetajat juba, et mida mina tahaksin, et kes mina tahaksin olla.

Rõhutatakse praktika mõju ja töökogemuse rolli arusaamade laienemisel.

... no see viienda aasta metafoor, see on ilmselgelt (töö)kogemus, et ma pean olema vastavalt õpilasele, vastavalt klassile, tekitama selle emotsiooni, selle, noh mõtte või nende jaoks, nende jaoks tunni 
tegema nagu sobivaks. Et ma võin minna ise ühe emotsiooniga, ühe mõttega, et me teeme nii, aga kui sa lähed klassi, sa vaatad, appi, me peame tegema teistmoodi. Et hoopis, et hüppad nagu teise olekusse.

Õpetaja pedagoogilise asjatundlikkuse väärtustamine enamikus metafoorides on intervjuudele toetudes suuresti õpetajakoolituse ainete mõju tulem.

... see, magistri oma on kindlasti tulnud selle kasvatusteaduste ainete pärast. Et just see kasvatuse pool ...

... sellepärast see psühholoog, ma arvan, et seda meile on küllaltki korrutatud ka, et õpetaja on ka psühholoogi eest, et ta peab õpilaste mured lihtsalt ära kuulama ja seda on nagu tähtsustatud hästi palju. ... Et ongi, et sa pead õpilase hingeelu ka tundma nagu. See on nagu hästi-hästi läbi räägitud meil, peaaegu igas loengus.

Küsimusele, mis on õpingute jooksul mõjutanud kõige tugevamalt õpetajaks kujunemist ja õpetamise mõtestamist, vastasid kõik intervjueeritud, et see on pedagoogiline praktika. Seda võib ka mõista, sest arusaam endast kui professionaalist saabki kujuneda vaid praktika käigus. Praktika võimaldas näha õpetajatöö köögipoolt laiemalt, andis võimaluse end proovile panna ning testida oma teadmisi ja oskusi. Olulisena tuuakse esile suhtlemine õpilastega, mis on ka arusaadav, sest õpilastel, suhetel õpilastega ja nendega toimetulekul on suur mõju tulevase õpetaja professionaalse identiteedi kujunemisele (Lauriala \& Kukkonen, 2005).

... enne seda nagu ei osanud nagu midagi arvata. Aga jah, et see praktika, et ise saab nagu tunnetada, kuidas õpetada ja kuidas ópilased reageerivad, ja kõik see ..., sain positiivse emotsiooni sealt.

Teisalt mõjutavad professionaalse identiteedi kujunemist praktikasituatsioonis ka juhendajad, klassid ja koolikultuur, millega praktikal kokku puututakse.

... ma sain väga hea juhendaja, väga hea klassi ja siis ma olin oma praktikatel iga päev, siis ma ei tea 8-9ni koolimajas, siis tegime tunde ja õppisime ja mul oli, noh, tekkis täiesti selline südamesoov, et ma tean, et ma olen õiges kohas.

Praktikale lisaks nimetati olulise mõjutajana ainedidaktikaga seotud kursusi ja õpetajakoolituse aineid. Uuringu tulemused on sarnased Thomas ja Beauchampi (2007) uuringu tulemustega, kus samuti selgus, et õpetajakoolituse lõpetajate arusaamu õpetajaks olemisest mõjutasid 
kõige enam praktika ja didaktikaõpingud. Siinkohal tuleb ka märkida, et enamasti seostati ainedidaktikat, aga ka kasvatusteaduslikke aineid just konkreetse õppejõu nime ja tema õpetamistegevusega. Teoreetiliste, erialaainete olulisust õpetajaks kujunemisel nimetati viiel korral ning pea sama arv kordi mainiti ka erialaaineid, mille kvaliteediga rahul ei oldud või mille vajalikkuses õpetajakoolituse õppekavas kaheldi.

\section{Õpetajakoolituse üliõpilaste arenguteed}

Nii nagu eespool öeldud, ei olnud õpetaja profiilide loomine esialgu uurijatel plaanis, kuid andmeid analüüsides hakkasid välja joonistuma kindlad rühmad ning neid otsustati lähemalt uurida. Klasteranalüüsi ja intervjuude analüüsi tulemuste kõrvutamisest ilmnes, et mõned omadused esinesid uuringus osalenute seas korduvate mustritena, ning selle põhjal tundus eristuvat neli õpetaja identiteedi kujunemise profili. Kuna uuringu valim oli väike, siis ei saa artiklis esitatud profiilidesse jaotumist kindlasti pidada ammendavaks. Samas annavad tulemused vihjeid selle kohta, milliste tegurite kombinatsioonid võivad mõjutada tulevaste õpetajate professionaalse identiteedi kujunemist.

Esimest profiili esindavaid üliõpilasi võiks nimetada enesekindlateks: neid iseloomustab kindel soov õpetajakoolitusse tulla ja õpetajaks saada juba esimesest õpinguaastast ning nad hindavad õpingute vältel kõrgelt oma akadeemilist enesetõhusust. Kuigi neil puudub töökogemus, on neil tänu pedagoogilise praktika positiivsetele kogemustele ka suur enesetõhusus õpetajana, sh nii juhendamise, klassi juhtimise kui ka õpilaste kaasamise alaskaalal. Kuna suur enesetõhusus toetab õpetaja usku oma toimetulekusse, siis hindasid nad ka, et nad on kõige lähemal oma kujutlusele ideaalsest õpetajast (kümnepalliskaalal 7-8).

Teise profiili esindajaid võiks nimetada töökogemusega realistideks. Ka need üliõpilased on teinud väga teadliku õppekava- ja ametivaliku, nad hindasid kõrgelt oma akadeemilist enesetõhusust ning neil kõigil oli töökogemus (0,5-1,75 aastat). Võimalik, et tänu praktilisele töökogemusele ei hinnanud nad enda enesetõhusust õpetajana nii kõrgelt kui enesekindlate rühma esindajad. Töökogemusega realistid pidasid enda enesetõhusust õpetajana keskmiseks, sh klassi juhtimises oli nende enesehinnang keskmisest madalam. Klassijuhtimise alaskaala küsimused olid seotud ópilase ja klassi käitumise juhtimisega, nt „Kui palju suudate ette võtta selleks, et panna lapsi klassis käitumise kodukorda järgima?”, „Kui hästi suudate ohjata probleemseid õpilasi klassis?". Madalam hinnang enda toimetulekule selle alaskaala puhul pole üllatav, sest ka varasemad uuringud 
on näidanud, et just distsipliiniprobleemidega on algajad õpetajad kõige rohkem hädas (vt Veenman, 1984).

Kolmandasse profiili kuuluvad üliõpilased, keda võiks nimetada eneseleidjateks. Neid kõiki iseloomustavad teatud kahtlused õpingute jooksul õpetajakutse valiku õigsuses. Huvitav on siinjuures see, et kõigil neil tekib mingil hetkel just kahtlus enda ressursside piisavuses, sest „õpetajatöö on nii vastutusrikas ja nõuab nii palju”. Kõhklustest aitasid üle saada nii edukas praktikakogemus kui ka toetavad olulised inimesed. Õpingute lõpuks on neil kindel veendumus erialavaliku õigsuses ning nad kõik on asunud õpingute ajal tööle. Töökogemust on neil 0,5-2 aastat. Nende hinnangud oma akadeemilisele enesetõhususele on õpingute jooksul kõikunud (v.a ühel üliõpilasel) ning teatud õpinguetappidel antud madalamaid hinnanguid võib seostada intervjuudes kirjeldatud kahtluste ja eneseotsimise või üle jõu käiva koormusega. Hinnangud enesetõhususele õpetajana on pigem keskmised.

Neljanda rühma üliõpilasi võiks liigitada kahtlejateks. Siia tüüpi kuuluvad üliõpilased, kes õpingute alguses ei ole soovinud õpetajaks saada või on bakalaureuseõpingute lõpus hakanud selles soovis kahtlema või on õpetajakoolitusse tulek olnudki juhuslik valik, sest nad „ei leidnud peale bakalaureuse lópetamist tööd”. Nende hulgas on neid, kelle enesehinnang enda akadeemilisele enesetõhususele üliõpilasena on õpinguaastate vältel olnud madal, aga ka neid, kel on see olnud kogu aeg keskmine või kõikunud kõrge ja keskmise vahel. Kuigi selles, et õpetajaamet meeldib, on praktika jooksul kinnitust saadud, ei olda siiski väga kindlad enda oskustes ja toimetulekus, sh eriti klassi juhtimises. Neil puudub töökogemus ja nad tunnevad ebakindlust õpetajana tööleminekul. Kaheldakse täiskoormusega toimetulekus, kuid poole koormusega ei soovi koolid õpetajaid tööle võtta, lisaks soovitakse peale lõpetamist pühenduda veel tippspordile ja alles hiljem õpetajana tööle minna. Enesehinnangud enesetõhususele õpetajana on sarnased hinnangutega akadeemilisele enesetõhususele: need on kas läbivalt madalad, keskmised või kõiguvad erinevates enesetõhususe alaskaalades keskmisest kõrgeni. Kõik siia profiili kuuluvad üliõpilased olid tulevased aineõpetajad.

\section{Arutelu}

Kui enamik õpetajaks õppijaid puudutavaid uuringuid keskendub vaid ühele osale õpingutest - õpetajakoolitusele -, siis see pikiuuring võimaldas saada infot üliõpilaste arengu kohta juba enne õpetajakoolitusse tulekut. 
Arvestades, et õpetajakoolituses on keeruline täita õppekohti ning samas on koolides puudu (aine)õpetajaid, võimaldavad uuringu tulemused paremini mõista potentsiaalseid õpetajakoolitusse tulijaid ning toetada nende arengut juba enne õpetajakoolituse õpinguid. Tulevaste õpetajate arengu uurijad paluvad üliõpilastel tavaliselt õpetajakoolituse õpinguid meenutada, kuid paraku ei ole mälu alati usaldusväärne, mistõttu olid varasematel õpinguaastatel kogutud andmed suureks abiks läbitud õpingute analüüsil ja õpikogemuste interpreteerimisel.

Toetudes nii intervjuudele kui ka küsitluste käigus saadud andmete varasematele analüüsidele (Löfström \& Poom-Valickis, 2013), võib öelda, et õpetajakoolitusse tulijad on erineva tausta ja motiividega. Osal neist on väga selge siht ja soov õpetajaks saada juba õpingute alguses, teised on tulnud õppima esialgu mingit konkreetset ainet ning õpetajakoolitusse astumine on olnud kas juhuslik või ratsionaalsetel põhjustel tehtud valik (ametit on vaja, õpingud lihtsamad, kindel töö ja palk jms). Ent intervjuud näitavad ka seda, et enamikul ópetajakoolitusse tulijatest on suuresti just oma koolikogemuse tõttu naivistlik arusaam õpetajatööst. Selleks, et suurendada erialavaliku teadlikkust ning toetada õigete ja läbimõeldud valikute tegemist, tuleks pakkuda pedagoogilisi aineid ning võimalusi õpetajaks olemist kogeda juba bakalaureuseastmes. Eriti oluline on see nn kahtleja profiilitüüpi kuuluvate üliõpilaste, aga ka eneseleidjate puhul. Õpetaja tegelik töömaht, oodatavad oskused ja nõudmised panevad nii mõnedki üliõpilased ópingute ajal kahtlema enda suutlikkuses nendele ootustele vastata.

Smythile (1989) toetudes võib öelda, et areng ja muutus on eelkõige eneseteadvustamise ja -tundmise tulemus. Suurem tähelepanu refleksioonioskustele, enda arusaamade ja uskumuste, aga ka pädevuse analüüsile võimaldab kujundada adekvaatsemat pilti endast kui tulevasest õpetajast ning selgemini märgata ka enda arenguvõimalusi. See on tähtis kõigi profiilide puhul, sest näiteks enesekindlatel võib suur enesetõhusus olla ka ohukoht, sest nad võivad luua ebaadekvaatse pildi enda toimetulekust õpetajana. Enda ressursside analüüs ja nõustamine toetaks oluliselt ka eneseleidja ja kahtleja profiili kuulujaid läbimõeldud valikute tegemisel. Refleksioon kui n-ö seestpoolt juhitav õppimine (Korthagen \& Vasalos, 2005) toetab samuti kutseoskuste arengut, sest selle kaudu püüab inimene mõista ja mõtestada oma kogemusi, õppida ja leida võimalusi uuel moel tegutsemiseks. McAlpine ja Weston (2002) on nentinud, et oma töö pidev analüüsimine ja selle alusel otsuste langetamine ühendavad teadmised praktilise tegevusega, mis on oluline niihästi uute teadmiste loomisel kui ka kasutamisel. Kasvanud teadmiste hulk suurendab omakorda suutlikkust 
reflekteerida ja õpetajana areneda. Paraku on varasemad uuringud näidanud, et refleksioonioskuste tase on algajatel õpetajatel suhteliselt madal (Poom-Valickis, 2008) ning sellele tuleks õpetajakoolituses senisest enam tähelepanu pöörata.

Professionaalse arengu ja õpetaja identiteedi kujunemise seisukohast ei ole oluline mitte ainult küsimus „Kes ma olen?”, vaid ka „Milline on minu ideaal?", sest ideaalid loovad kujutluspildi eesmärgist, mille suunas professionaalina kavatsetakse liikuda. Analüüsides intervjueeritavate õpetaja ideaali kirjeldusi, võib öelda, et aineõpetajate professionaalse identiteedi loomisel on tähtis koht ainel. Klassiõpetajate ideaalne õpetaja on enam keskendunud õppeprotsessile kui tervikule ning suhetele õpilastega. Tulevaste õpetajate ideaalide kujunemist on mõjutanud eelkõige isiklik koolikogemus, enda kunagised oppetajad, kelle moodi soovitakse olla. Ent ideaalide kirjeldamisel on tähtis osa ka kujutlustel, millisena tahetakse ennast ja eelkõige suhteid õpilastega tulevikus näha. Tulevased aineõpetajad soovivad, et neid austatakse ja õpilased peaksid neist lugu. Klassiõpetajatele on oluline, et kõik õpilased tunneksid end klassiruumis hästi ja turvaliselt ning nemad õpetajana oleksid neile eeskujuks. Huvitav on siinkohal see, et kuigi öeldakse, et üks ideaali loomist mõjutavaid põhikomponente on seotud isikuomadustega ning need omakorda ühiskondlike arusaamadega ja rollile esitatavate normide ja ootustega (De Ruyter \& Conroy, 2002), mainisid konkreetseid isikuomadusi oma õpetajaideaali kirjeldamisel eelkõige klassiõpetajad. Ideaalne klassiõpetaja on rõõmus, paindlik ja aktiivne.

Nii metafooride kui ka intervjuude analüüsi põhjal võib öelda, et üliõpilaste arusaam õpetaja rollist on õpingute ajal muutunud komplekssemaks, keerulisemaks. Intervjuudest selgub, et just pedagoogiline praktika mõjutab tulevase õpetaja identiteedi kujunemist kõige tugevamalt, mis on ka mõistetav, sest professionaalne identiteet saab kujuneda praktika käigus, kus oma teadmisi, oskusi, aga ka uskumusi ja arusaamu proovile pannakse. Pedagoogiline praktika võimaldab testida nii oma arusaamu õpetajaks olemisest kui ka õpetajana toimetulekust. Sarnastele tulemustele on jõudnud ka teised uurijad (Anspal et al., 2012; Thomas \& Beauchamp, 2007; Timoštšuk \& Ugaste, 2010). Kõik 13 üliõpilast kinnitasid intervjuudes, et praktika oli see, kus saadi lõplik kinnitus erialavaliku õigsusele. Samas on pedagoogiline praktika üks osa õpetajakoolituse õpingutest, mida hinnatakse, ning see eeldab seega teatud normidest lähtuvat ja ootustele vastavat tegutsemist. See, kuivõrd üliõpilane mugandub juhendava õpetaja tööstiiliga või saab oma tegelikku mina proovile panna, sõltub nii üliõpilasest, juhendavast õpetajast kui ka koolikontekstist. 
Sellest johtuvalt tuleks tähelepanu pöörata praktika juhendamise kvaliteedile. Ühelt poolt on tähtis, et peale pedagoogiliste oskuste analüüsi suunaksid praktika juhendajad tulevast õpetajat teadlikumalt ka oma professionaalse identiteedi analüüsile, kuid teisalt peaksid nad looma võimalusi oma ideaalmina proovilepanekuks reaalses klassisituatsioonis. Õpetajaks õppijate professionaalse identiteedi loomise protsessi saab oluliselt toetada, kui praktika juhendajad on teadlikud ja huvitatud tulevaste õpetajate eesmärkidest, soovidest ja ideaalidest ning sobitaksid (kasvõi osaliselt) enda suuniseid ja standardeid nendega (Lauriala \& Kukkonen, 2005).

Veel üks aspekt, millele tasuks õpetajakoolituse õppekavade arendamisel tähelepanu pöörata, on õppekava kui tervik, kuhu kuuluvad peale kasvatusteaduslike ainete, ainedidaktika ja pedagoogilise praktika ka erialaained. Intervjueeritavad tõstsid pedagoogilise praktika kõrval esile kasvatusteaduslikke aineid ja ainedidaktikat ning vaid viiel korral nimetati mõningaid erialaaineid. Õpetaja ainealane kompetentsus on vaieldamatult oluline, kuid erialaaineid tuleks tulevase professiooniga paremini siduda. Niisamuti tuleks silmas pidada, et õppijate koolikogemus ja õpetajad, aga ka ülikooli õppejõud ja praktikajuhendajad on õpetajakoolituse üliõpilaste professionaalse identiteedi kujunemisel eeskujuks, kelle viidatud ametinorme ja -standardeid suhestavad õppijad tegeliku ja ideaalmina pildiga. Intervjuude põhjal enim üliõpilase kujunemist mõjutanud ainete puhul ilmnes selge seos seda õpetava õppejõu isikuga. Seega on ülikooli õppejõud tulevaste õpetajate jaoks olulised rollimudelid (Loughran \& Berry, 2005).

Õpetajakoolituse praktikaülesannete raames suunatakse õpetajaks õppijaid reflekteerima pedagoogilise praktika käigus saadud kogemusi, kuid õppijatelt tuleks ka küsida, kuidas nad näevad oma professiooni, ennast õpetajana ning milline on see õpetaja, kelleks nad tahavad saada, ning miks on just see neile oluline? Mõistes, et arusaam oma professionaalsest identiteedist on õpetajakoolituse lõpus alles kujunemisjärgus, tuleks õpetajakoolituses pöörata tähelepanu identiteedi arengu toetamisele. Tulevaste õpetajate suunamine oma professionaalse identiteedi teadlikumale analüüsile ja mõtestamisele peaks olema üks aspekte, millele õpetajakoolituses keskenduda.

\section{Tänusõnad}

Uuringut toetas Euroopa Sotsiaalfondi programm Eduko SA Archimedese kaudu (grant 30.2-4/549). 


\section{Kasutatud kirjandus}

Akkerman, S. F., \& Meijer, P. C. (2011). A dialogical approach to conceptualizing teacher identity. Teaching and Teacher Education, 27(2), 308-319. http://dx.doi.org/10.1016/j.tate.2010.08.013

Alger, C. L. (2009). Secondary teachers' conceptual metaphors of teaching and learning: Changes over the career span. Teaching and Teacher Education, 25(5), 743751. http://dx.doi.org/10.1016/j.tate.2008.10.004

Anspal, T., Eisenschmidt, E., \& Löfström, E. (2012). Finding myself as a teacher exploring the shaping of teacher identities through student teachers' narratives. Teachers and Teaching: Theory and Practice, 18(2), 197-216.

http://dx.doi.org/10.1080/13540602.2012.632268

Beauchamp, C., \& Thomas, L. (2009). Understanding teacher identity: An overview of issues in the literature and implications for teacher education. Cambridge Journal of Education, 39(2), 175-189. http://dx.doi.org/10.1080/03057640902902252

Beauchamp, C., \& Thomas, L. (2010). Reflecting on an ideal: Student teachers envision a future identity. Reflective Practice, 11(5), 631-643. http://dx.doi.org/10.1080/14623943.2010.516975

Beijaard, D. (1995). Teachers' prior experiences and actual perceptions of professional identity. Teachers and Teaching: Theory and Practice, 1(2), 281-294. http://dx.doi.org/10.1080/1354060950010209

Beijaard, D., Meijer, P., \& Verloop, N. (2004). Reconsidering research on teachers' professional identity. Teaching and Teacher Education, 20(2), 107-128. http://dx.doi.org/10.1016/j.tate.2003.07.001

Beijaard, D., Verloop, N., \& Vermunt, J. D. (2000). Teachers' perceptions of professional identity: An exploratory study from a personal knowledge perspective. Teaching and Teacher Education, 16(7), 749-764. http://dx.doi.org/10.1016/S0742-051X(00)00023-8

Berliner, D. (1987). Ways of thinking about students and classrooms by more and less experienced teachers. In J. Calderhead (Ed.), Exploring teachers' thinking (pp. 60-83). London: Cassell.

Braun, V., \& Clarke, V. (2006). Using thematic analysis in psychology. Qualitative Research in Psychology, 3(2), 77-101. http://dx.doi.org/10.1191/1478088706qp063oa

Bullough, R. V., Jr. (1991). Exploring personal teaching metaphors in preservice teacher education. Journal of Teacher Education, 42(1), 43-51. http://dx.doi.org/10.1177/002248719104200107

Calderhead, J. (1996). Teachers: Beliefs and knowledge. In D. C. Berliner \& R. C. Calfee (Eds.), Handbook of Educational Psychology (pp. 709-725). New York: McMillan.

Day, C., Kington, A., Stobart, G., \& Sammons, P. (2006). The personal and professional selves of teachers: Stable and unstable identities. British Educational Research Journal, 32(4), 601-616. http://dx.doi.org/10.1080/01411920600775316

De Ruyter, D., \& Conroy, J. (2002). The formation of identity: The importance of ideals. Oxford Review of Education, 28(4), 509-522.

http://dx.doi.org/10.1080/0305498022000013643 
Flores, M. A., \& Day, C. (2006). Context which shape and reshape new teachers' identities: A multi-perspective study. Teaching and Teacher Education, 22(2), 219-232. http://dx.doi.org/10.1016/j.tate.2005.09.002

Freese, A. R. (2006). Reframing one's teaching: Discovering our teacher selves through reflection and inquiry. Teaching and Teacher Education, 22(1), 110-119. http://dx.doi.org/10.1016/j.tate.2005.07.003

Furlong, C. (2013). The teacher I wish to be: Exploring the influence of life histories on student teacher idealised identities. European Journal of Teacher Education, 36(1), 68-83. http://dx.doi.org/10.1080/02619768.2012.678486

Haamer, A. (2012). Ideaalide kaudu professionaalse identiteedini. Acta semiotica Estica, IX, 201-225.

Joram, E., \& Gabriele, A. J. (1998). Preservice teachers' prior beliefs: Transforming obstacles into opportunities. Teaching and Teacher Education, 14(2), 175-191. http://dx.doi.org/10.1016/S0742-051X(97)00035-8

Kagan, D. M. (1992). Professional growth among preservice and beginning teachers. Review of Educational Research, 62(2), 129-169. http://dx.doi.org/10.3102/00346543062002129

Karm, M. (2007). Eesti täiskasvanukoolitajate professionaalsuse kujunemise võimalused (Doktoriväitekiri). Tallinna Ülikooli Kirjastus, Tallinn.

Kelchtermans, G., \& Vandenberghe, R. (1994). Teachers' professional development: A biographical perspective. Journal of Curriculum Studies, 26(1), 45-62. http://dx.doi.org/10.1080/0022027940260103

Korthagen, F. (2004). In search of the essence of a good teacher: Towards a more holistic approach in teacher education. Teaching and Teacher Education, 20(1), 77-97. http://dx.doi.org/10.1016/j.tate.2003.10.002

Korthagen, F., \& Vasalos, A.(2005). Levels in reflection: Core reflection as a means to enhance professional growth. Teachers and Teaching, 11(1), 47-71.

http://dx.doi.org/10.1080/1354060042000337093

Lauriala, A., \& Kukkonen, M. (2005). Ammatillisen identiteeti rakentuminen harjoittelusituaatioissa. In P. Väisänen \& P. Atjonen (Eds.), Kohtaamisia ja kasvun paikkoja opetusharjoittelussa:Vuoropuhelua ohjauksen kehittämisestä. Suomen harjoittelukoulujen vuosikirja 3 (pp. 91-107). Joensuu: Joensuun Yliopistopaino.

Leavy, A. M., McSorley, F. A., \& Bote, L. A. (2007). An examination of what metaphor construction reveals about the evolution of preservice teachers' beliefs about teaching and learning. Teaching and Teacher Education, 23(7), 1217-1233. http://dx.doi.org/10.1016/j.tate.2006.07.016

Leijen, Ä., \& Kullasepp, K. (2013). All roads lead to Rome: Developmental trajectories of student teachers' professional and personal identity development. Journal of Constructivist Psychology, 26(2), 104-114. http://dx.doi.org/10.1080/10720537.2013.759023

Lortie, D. (1975). Schoolteacher: A sociological study. Chicago: University of Chicago Press.

Loughran, J., \& Berry, A. (2005). Modelling by teacher educators. Teaching and Teacher Education, 21(2), 193-203. http://dx.doi.org/10.1016/j.tate.2004.12.005

Löfström, E., Anspal, T., Hannula, M. S., \& Poom-Valickis, K. (2010a). Metaphors about 'the teacher': Gendered, discipline-specific and persistent? In J. Mikk, 
M. Veisson, \& P. Luik (Eds.), Teacher's personality and professionalism. Estonian Studies in Education (Vol. 2, pp. 105-122). Frankfurt am Main: Peter Lang.

Löfström, E., \& Poom-Valickis, K. (2013). Beliefs about teaching: Persistent or malleable? A longitudinal study of prospective student teachers' beliefs. Teaching and Teacher Education, 35, 104-113. http://dx.doi.org/10.1016/j.tate.2013.06.004

Löfström, E., Poom-Valickis, K., Hannula, M. S., \& Mathews, S. (2010b). Supporting emerging teacher identities: Can we identify teacher potential among students? European Journal of Teacher Education, 33(2), 167-184. http://dx.doi.org/10.1080/02619761003631831

Martínez, M. A., Sauleda, N., \& Huber, G. L. (2001). Metaphors as blueprints of thinking about teaching and learning. Teaching and Teacher Education, 17(8), 965-977. http://dx.doi.org/10.1016/S0742-051X(01)00043-9

McAlpine, L., \& Weston, C. (2002). Reflection: Improving teaching and students learning. In N. Hativa \& P. Goodyear (Eds.), Teacher thinking, beliefs and knowledge in higher education (pp. 59-77). Dordrecht: Kluwer Academic Publishers. http://dx.doi.org/10.1007/978-94-010-0593-7_4

Pajares, F. M. (1992). Teachers' beliefs and educational research: Cleaning up a messy construct. Review of Educational Reserch, 62(3), 307-332. http://dx.doi.org/10.3102/00346543062003307

Pillen, M. T., Brok, D. P. J., \& Beijaard, D. (2013). Profiles and change in beginning teachers' professional identity tensions. Teaching and Teacher Education, 34, 86-97. http://dx.doi.org/10.1016/j.tate.2013.04.003

Pinnegar, S., Mangelson, J., Reed, M., \& Groves, S. (2011). Exploring preservice teachers' metaphor plotlines. Teaching and Teacher Education, 27(3), 639-647. http://dx.doi.org/10.1016/j.tate.2010.11.002

Poom-Valickis, K. (2008). Novice teachers' professional development across their induction year (Doctoral dissertation). Tallinn University, Tallinn.

Richardson, V. (1996). The role of attitudes and beliefs in learning to teach. In J. Sikula (Ed.), Handbook of research on teacher education (pp. 102-119). New York: McMillan.

Saban, A. (2004). Prospective classroom teachers' metaphorical images of selves and comparing them to those they have of their elementary and cooperating teachers. International Journal of Educational Development, 24(6), 617-635. http://dx.doi.org/10.1016/j.ijedudev.2004.03.003

Saban, A. (2010). Prospective teachers' metaphorical conceptualizations of learner. Teaching and Teacher Education, 26(2), 290-305. http://dx.doi.org/10.1016/j.tate.2009.03.017

Smagorinsky, P., Cook, L. S., Moore, C., Jackson, A. Y., \& Fry, P. G. (2004). Tensions in learning to teach: Accommodation and the development of a teaching identity. Journal of Teacher Education, 55(1), 8-24. http://dx.doi.org/10.1177/0022487103260067

Smyth, J. (1989). Developing and sustaining critical reflection in teacher education. Journal of Teacher Education, 40(2), 2-9. http://dx.doi.org/10.1177/002248718904000202 
Thomas, L., \& Beauchamp, C. (2007). Learning to live well as teachers in changing world: Insights into developing a professional identity in teacher education. Journal of Educational Thought, 41(3), 229-243.

Thomas, L., \& Beauchamp, C. (2011). Understanding new teachers' professional identities through metaphor. Teaching and Teacher Education, 27(4), 762-769. http://dx.doi.org/10.1016/j.tate.2010.12.007

Timoštšuk, I., \& Ugaste, A. (2010). Student teachers' professional identity. Teaching and Teacher Education, 26(8), 1563-1570. http://dx.doi.org/10.1016/j.tate.2010.06.008

Veenman, S. (1984). Perceived problems of beginning teachers. Review of Educational Research, 54(2), 143-178. http://dx.doi.org/10.3102/00346543054002143 
Lisa 1. Ülevaade pikiuuringu käigus eri aastatel kogutud andmetest

\begin{tabular}{|c|c|c|c|}
\hline Aasta & $N$ & Õppetase & Andmekogumismeetodi kirjeldus \\
\hline 2008 & 310 & BA I & $\begin{array}{l}\text { Küsimustik } \\
\text { Põhjused kõrgkooliõpingute valikul ning õppekava valiku } \\
\text { motiivide selgus } \\
\text { Akadeemiline enesetõhusus* - adapteerinud Must, 2006, Robbins } \\
\text { et al., } 2004 \text { järgi; Chemers, Hu \& Garcia, } 2000 \\
\text { Kõrgkoolis õppimise kogemused (alaskaalad: organisatsioon } \\
\text { ja struktuur, õpetamine ja õppimine, üliõpilased ja õppejõud, } \\
\text { hindamine ja iseseisvad tööd, üldine rahulolu) - Learning and } \\
\text { Studying Questionnaire (LSQ) } \\
\text { Õpetajakoolituse/õpetajaameti valiku tõenäosus* } \\
\text { Õpetajaameti valiku võimalikud põhjused* - mõõdik põhineb: } \\
\text { Kyriacou \& Coulthard, 2000 } \\
\text { Uskumused - mõõdik põhineb: Teachers' perceptions of } \\
\text { professional identity; Beijaard, Verloop, \& Vermunt, } 2000 \\
\text { Uskumused: metafoor koos põhjendusega* }\end{array}$ \\
\hline 2010 & 163 & BA III & $\begin{array}{l}\text { Küsimustik } \\
\text { Akadeemiline enesetõhusus* - Must, } 2006 \\
\text { Üldine rahulolu õpingutega } \\
\text { Õpetajakoolituse/õpetajaameti valiku tõenäosus* } \\
\text { Õpetajaameti valiku võimalikud põhjused* - mõõdik põhineb: } \\
\text { Kyriacou \& Coulthard, } 2000 \\
\text { Uskumused - mõõdik põhineb: Teachers' perceptions of } \\
\text { professional identity; Beijaard, Verloop, \& Vermunt, } 2000 \\
\text { Uskumused: metafoor koos põhjendusega* }\end{array}$ \\
\hline 2012 & 55 & $\begin{array}{l}\text { MA (õpe- } \\
\text { tajakooli- } \\
\text { tus) }\end{array}$ & $\begin{array}{l}\text { Küsimustik } \\
\text { Akadeemiline enesetõhusus* - Must, } 2006 \\
\text { Õpetajakoolituse/õpetajaameti valiku tõenäosus* } \\
\text { Õpetajaameti valiku võimalikud põhjused* - mõõdik põhineb: } \\
\text { Kyriacou \& Coulthard, } 2000 \\
\text { Enesetõhusus õpetajana* (alaskaalad: juhendamine, klassi- } \\
\text { juhtimine, õpilaste kaasamine) - Ohio State Teacher Efficacy Scale } \\
\text { (OSTES); Tschannen-Moran \& Woolfolk Hoy, } 2001 \\
\text { Uskumused - mõõdik põhineb: Teachers' perceptions of } \\
\text { professional identity; Beijaard, Verloop, \& Vermunt, } 2000 \\
\text { Uskumused: metafoor koos põhjendusega* }\end{array}$ \\
\hline
\end{tabular}




\begin{tabular}{|c|c|c|c|}
\hline 2013 & 15 & $\begin{array}{l}\text { MA (õpe- } \\
\text { tajakooli- } \\
\text { tus) }\end{array}$ & $\begin{array}{l}\text { Intervjuu küsimused } \\
\text { 1. Vaadates tagasi viiele õpinguaastale ülikoolis, siis mis on } \\
\text { olnud need olulised pöördepunktid või sündmused, mis on } \\
\text { mõjutanud Sinu arusaamu õpetamisest ja õppimisest? Kui } \\
\text { Sinu arvamused, arusaamad on õpingute jooksul muutunud, } \\
\text { siis miks? } \\
\text { 2. Kuidas on õpetajakoolituse programm mõjutanud Sinu } \\
\text { arusaamu õpetamisest? Millised konkreetsed aspektid } \\
\text { programmist (kursused, praktikum jne) on mõjutanud Sinu } \\
\text { arusaamu? Millised on Sinu arvates olnud kõige kasulikumad } \\
\text { õpetajahariduse programmi aspektid, mis on toetanud Sinu } \\
\text { kui tulevase õpetaja arengut? } \\
\text { 3. Kuidas Sa kujutad ette oma esimest aastat õpetajana? Palun } \\
\text { kirjelda seda. } \\
\text { 4. Kas Sul on ettekujutus sellest, milline õpetaja Sa tahaksid olla? } \\
\text { Kas Sa palun kirjeldaksid seda? } \\
\text { 5. Kui kaugel Sa enda arvates hetkel kümnepalliskaalal sellest } \\
\text { ideaalist oled? Kuidas Sa arvad, et jõuad selle ideaalini? } \\
\text { 6. Sa oled kirjeldanud õpetaja rolli selliste metafooride kaudu } \\
\text { nagu .... ja .... ja .... Mis võisid olla need põhjused, et kirjeldasid } \\
\text { õpetaja rolli just nii? Kas sooviksid nüüd kasutada teistsugust } \\
\text { metafoori? } \\
\text { 7. Mida Sa muudaksid õpetajahariduse õppekavas, et õpetajaks } \\
\text { õppijate arengut paremini toetada? }\end{array}$ \\
\hline
\end{tabular}

Märkus. * - küsimuste plokid, mida kasutati taustinfona intervjuude analüüsimisel. 


\title{
A longitudinal study of the development of the professional identity of student teachers
}

\author{
Katrin Poom-Valickis ${ }^{\mathrm{a} 1}$, Erika Löfström ${ }^{\mathrm{b}}$ \\ a Tallinn University, Institute of Educational Sciences \\ ${ }^{b}$ University of Helsinki, Institute of Behavioural Sciences
}

\begin{abstract}
Summary
The development of teachers' professional identity has been defined as "an on-going and dynamic process which entails the making sense and (re)interpretation of one's own values and experiences" that have been influenced by personal, social and cognitive factors (Flores \& Day, 2006).

From the viewpoint that identity consists of meanings formed from moments and situations with relevance for the individual and by being hierarchically organised from the individual's self-conception (Haamer, 2012), student teachers can be viewed as "developing selves", gradually developing an understanding of one's professional self, based on interactions with significant others and the environment (Lauriala \& Kukkonen, 2005).

In the current paper, based on interviews $(N=13)$ carried out at the end of a longitudinal study, we present an overview of the development of the professional identity of student teachers who have finished a five-year long teacher training programme. The aim of the study was to examine the meanings and beliefs behind student teachers' teacher-identity formed in interaction with the surrounding environments, including the experiences from their studies at university. As memory enhancers, we used metaphors that the students had used during their studies, and also data from earlier data collections. In the current paper we try to answer the following questions: How do students who have finished their teacher training studies interpret their teacher identity formation throughout their studies? What kind of teacher identity do student teachers wish to strive toward based on their perception of the ideal teacher? Which factors during the training period have influenced student teachers' conceptions the most?
\end{abstract}

1 Institute of Educational Sciences, Tallinn University, Narva Road 25, 10120 Tallinn, Estonia; katrinpv@tlu.ee 
We used thematic analysis (Braun \& Clarke, 2006) to examine the interview data and the model by Beijaard, Verloop and Vermunt (2000) to analyse the metaphors. The model entails foundations for the formation of teachers' professional identity by teachers' conceptions of themselves as either subject matter experts, pedagogical experts, or didactical experts (usually combining those three). In order to gain a better overview of within-group differences and similarities in development, we used cluster analysis based on the Euclidean distance.

It appears from the interviews that subjects reported naïve conceptions of teaching while entering the teacher education programme, relying mostly on their personal school experience. In their descriptions of ideal teachers, those learning to become subject teachers, mostly stressed aspects associated with the subject matter and teaching the subject matter, whereas future class-teachers were more focused on relationships with pupils and the learning process as a whole. The ideal for a subject teacher was a well-respected teacher, looked up to by the pupils. The ideal for a class-teacher was an energetic, happy and flexible person who would serve as a good role-model for the children. Interview subjects associated the image of an ideal teacher first and foremost with the classroom and only two of the student teachers incorporated expectations toward co-workers and the school as an organisation into their teacher ideal.

Student teachers' ideals have been influenced by their previous teachers as role-models, images of ideal situations, where one wishes to find oneself in the future as well as common understandings of the norms and expectations put on a teacher. Evaluations of the distances between the current self and the ideal self differed by between four and eight points on a ten-point scale. The closest to their ideal self according to their selfreport were the students who also reported the highest self-efficacy scores in the group.

When comparing metaphors given by the student teachers at the beginning and at the end of their studies, we found that the conception of a teacher's role has become more diverse. The number of one-dimensional metaphors had decreased, whereas the number of hybrid metaphors had gone up. The changes apparent in the metaphors coincide with the interviews, as all the subjects reported that their views had changed during their studies. The student teachers asserted that the metaphors from their bachelor-years to a large extent reflected their personal experience as school children and their ideal teachers as well as the focus on subject matter training during their first years as students. The changes are evident in master-level students' conceptions about the role of the 
teacher and hence also the metaphors are accounted for by a clarified understanding of teacher's role during the subjects of teacher education as well as the influence of the pedagogical practice. Based on the interviews, it can be said that stressing the importance of pedagogical expertise in most of the metaphors can be accounted for by the content of the teacher training courses. In accordance with earlier studies, pedagogical practice has the most important role to play in the formation of the identity of the future teacher.

Comparing the results from the cluster analysis and the interviews, it appeared that certain attributes of our research subjects seemed to occur as repeating patterns, from which four profiles of teacher identity formation emerged: the self-efficacious, the experienced realists, the identity-searchers, and the doubtful. These clusters embody different teacher identities and it is important to understand these because novice teachers consequently enter the profession with different orientations. The orientations will require different support, especially the identitysearchers and the doubtful.

Based on interviews, we can say that people entering the teacher education programme represent different backgrounds and motives. Some have very explicit goals of becoming a teacher already at the very beginning, others have started with different subjects at university and entered the teacher education programme only later either by chance or through rational considerations (need for a profession, easier curriculum, secure job and pay, etc.). As development and change occurs mainly through self-awareness and self-knowledge, more attention toward self-reflection abilities as well as the skills necessary to analyse one's conceptions, beliefs and competencies will help support the formation of a more adequate image future teachers have of themselves and also to notice one's possibilities for development. Hence, guiding future teachers toward a more conscious and informed analysis of their professional identity should be one of the aspects stressed more in teacher education.

Keywords: teacher education, identity, professional identity 